University of Nebraska - Lincoln

DigitalCommons@University of Nebraska - Lincoln

Publications, Agencies and Staff of the U.S.

Department of Commerce

U.S. Department of Commerce

$7-2008$

\title{
Use of Chemical Tracers to Assess Diet and Persistent Organic Pollutants in Antarctic Type C Killer Whales
}

Margaret Krahn

NOAA Fisheries, Northwest Fisheries Science Center, 2725 Montlake Boulevard East, Seattle, Washington

Robert Pitman

Southwest Fisheries Science Center, 8604 La Jolla Shores Drive, La Jolla, California

Douglas Burrows

NOAA Fisheries, Northwest Fisheries Science Center, 2725 Montlake Boulevard East, Seattle, Washington

David Herman

NOAA Fisheries, Northwest Fisheries Science Center, 2725 Montlake Boulevard East, Seattle, Washington

Ronald Pearce

NOAA Fisheries, Northwest Fisheries Science Center, 2725 Montlake Boulevard East, Seattle, Washington

Follow this and additional works at: https://digitalcommons.unl.edu/usdeptcommercepub

Part of the Environmental Sciences Commons

Krahn, Margaret; Pitman, Robert; Burrows, Douglas; Herman, David; and Pearce, Ronald, "Use of Chemical Tracers to Assess Diet and Persistent Organic Pollutants in Antarctic Type C Killer Whales" (2008). Publications, Agencies and Staff of the U.S. Department of Commerce. 29.

https://digitalcommons.unl.edu/usdeptcommercepub/29

This Article is brought to you for free and open access by the U.S. Department of Commerce at DigitalCommons@University of Nebraska - Lincoln. It has been accepted for inclusion in Publications, Agencies and Staff of the U.S. Department of Commerce by an authorized administrator of DigitalCommons@University of Nebraska - Lincoln. 


\title{
Use of chemical tracers to assess diet and persistent organic pollutants in Antarctic Type C killer whales
}

\author{
MARGARET M. KRAHN \\ NOAA Fisheries, \\ Northwest Fisheries Science Center, \\ 2725 Montlake Boulevard East, \\ Seattle, Washington 98112, U.S.A. \\ E-mail: peggy.krahn@noaa.gov

\section{ROBERT L. PitMAN} \\ NOAA Fisheries, \\ Southwest Fisheries Science Center, \\ 8604 La Jolla Shores Drive, \\ La Jolla, California 92037, U.S.A. \\ DOUglas G. Burrows \\ DAVID P. HERMAN \\ Ronald W. Pearce \\ NOAA Fisheries, \\ Northwest Fisheries Science Center, \\ 2725 Montlake Boulevard East, \\ Seattle, Washington 98112, U.S.A.
}

\begin{abstract}
Measuring chemical tracers in tissues of marine predators provides insight into the prey consumed and the predator's contaminant exposure. In this study, samples from Type C killer whales (Orcinus orca) biopsied in Antarctica were analyzed for chemical tracers (i.e., stable isotopes of carbon and nitrogen, fatty acids, and persistent organic pollutants [POPs]). Profiles of these individual tracers were very different from those of killer whale populations that have been studied in the eastern North and eastern Tropical Pacific. For example, $\delta^{13} \mathrm{C}$ and $\delta^{15} \mathrm{~N}$ stable isotope values and most POP concentrations were significantly lower in the Antarctic population. In addition, multivariate statistical analyses of both fatty acid and POP profiles found distinctly different patterns for Antarctic Type $C$ whales compared to those from whales in the other populations. Similar assays were conducted on four species of Antarctic marine fish considered potential prey for Type $C$ killer whales. Results were consistent with a diet of fish for Type $C$ whales, but other species (e.g., low trophic-level marine mammals or penguins) could not be eliminated as supplemental prey.
\end{abstract}

Key words: killer whale, Orcinus orca, diet, prey, biopsy sampling, stable isotopes, fatty acids, persistent organic pollutants, Antarctica. 
Killer whales (Orcinus orca) occupy the top level of many marine food webs. This species is locally common in the world's oceans, particularly at the higher latitudes, and occurs in either localized resident populations or in wider ranging groups (Forney and Wade 2006). Killer whales have been well studied in certain regions, notably the eastern North Pacific (ENP) where three different forms have been identified-the marine-mammal eating "transients," the fish-eating "residents," and the "offshores" that currently are thought to eat primarily fish (Bigg 1982, Jones 2006). These "ecotypes" are genetically distinct (Hoelzel et al. 1998), differing in various aspects of morphology and behavior (Ford et al. 2000), acoustics (Barrett-Lennard et al. 1996), and habitat use (Ford et al. 1998). It has been suggested that these differences contribute to reproductive isolation and perhaps incipient speciation among the different forms (Baird et al. 1992).

Observations on killer whales in the Southern Hemisphere, e.g., Antarctica and New Zealand, also suggest ecotypic variation (Jehl et al. 1980, Mikhalev et al. 1981, Thomas et al. 1981, Berzin and Vladimirov 1983, Gill and Thiele 1997, Visser 1999). Recently, Pitman and Ensor (2003) reported on the existence in Antarctic waters of three ecologically and morphologically distinct forms of killer whales that apparently also show dietary specialization. Whales designated as "Type A" are thought to feed predominantly on Antarctic minke whales (Balaenoptera bonaerensis), "Type B" are believed to preferentially feed on pinnipeds, but they may also occasionally supplement their seal diet with cetaceans and penguins, and "Type C" are thought to prey mainly on marine fish. Type $\mathrm{C}$ killer whales have been observed carrying large Antarctic toothfish (Dissostichus mawsoni) in their mouths (Pitman and Ensor 2003). Although field observers have also reported that Type $C$ whales interact with other marine mammals and penguins (Pitman and Ensor 2003, Ballard and Ainley 2005), no predation has been observed. In fact, Type C killer whales in McMurdo Sound are regularly observed ignoring Adélie Penguins (Pygoscelis adeliae), Weddell seals (Leptonychotes weddellii), and Antarctic minke whales that often occur in close proximity (RLP, personal observations).

Studying the diet and trophic position of top-level marine predators, such as killer whales, is essential in understanding their role in marine food webs. Unfortunately, diet composition derived solely from field sightings of feeding events has some important limitations because these observations: (1) tend to be relatively rare, especially for fish eaters; (2) can be limited by season and weather; (3) may represent only short-term dietary habits; and (4) can be adversely and severely affected by other known biases (Tollit et al. 1997, Yonezaki et al. 2003, Ford and Ellis 2006). As a means of providing supplemental data on the feeding habits of killer whales, chemical tracers acquired via their prey can be measured to help identify (or conversely eliminate) certain species as likely prey. In addition, these chemical tracers can sometimes indicate broad geographic localities where foraging most likely occurred (Hooker et al. 2001, Krahn et al. 2007).

The two most common biochemical signals used for assessing trophic position and dietary preferences of marine mammals are fatty acid signature analysis of blubber (Iverson et al. 2004) and stable carbon and nitrogen isotope values in the epidermis (Kelly 2000). Initial studies that used fatty acid compositions to study the diet of pinnipeds (Walton et al. 2000) and cetaceans (Dahl et al. 2000) were qualitative in nature. In contrast, more recent studies using fatty acid signature analysis (Iverson et al. 2004) have shown that a quantitative assessment of the relative contribution of specific prey to the diets of marine mammals is possible. However, the extent to which individual fatty acids are selectively metabolized 
or biosynthesized by the predator must be quantitatively established through carefully controlled captive feeding studies. Furthermore, fatty acids of killer whales are significantly stratified throughout the blubber column (Krahn et al. 2004) and fatty acids from the inner layers - generally believed to be the most metabolically active - are expected to be best correlated with those of ingested prey (Koopman et al. 1996, Olsen and Grahl-Nielsen 2003). Free-ranging cetaceans, including killer whales, are most often sampled using biopsy darting techniques that acquire only the epidermis and outer blubber layer (Hoelzel et al. 1998, Barrett-Lennard 2000, Ylitalo et al. 2001). Consequently, any inferences about cetacean diets made from measurements of fatty acids in shallow biopsy blubber samples will be qualitative in nature.

Stable isotope ratios of nitrogen $\left({ }^{15} \mathrm{~N} /{ }^{14} \mathrm{~N}\right)$, and to a lesser extent carbon $\left({ }^{13} \mathrm{C} /{ }^{12} \mathrm{C}\right)$, show a stepwise enrichment with each increasing trophic level in the marine environment (DeNiro and Epstein 1978, 1981; Hobson and Welch 1992). Because these carbon and nitrogen isotope values reflect food consumed and assimilated, shifts in stable isotope values can be used to provide general information about the diet of a predator. Both carbon and nitrogen isotope values in the tissues of a predator are an approximately linear combination of the isotope values of all prey items consumed and their respective percentages of the diet within a certain period of time, modified to account for trophic enrichment. The specific time period is dependent on the tissue analyzed. For example, Tieszen et al. (1983) found that the half-life for $\delta^{13} \mathrm{C}$ values in gerbil tissues varied from $6.4 \mathrm{~d}$ in the liver to $27.6 \mathrm{~d}$ in muscle. Furthermore, trophic enrichment values vary for each species. The enrichment values can be roughly estimated for entire ecosystems (Wada et al. 1987, Hobson et al. 2002 ), but species-specific values can only be determined by feeding experiments in controlled environments (Tieszen et al. 1983, Hobson et al. 1996) or carefully monitored natural systems (Fox-Dobbs et al. 2007). Thus, even for specialist predators such as killer whales, stable isotope measurements can reveal whether a diet inferred from field observations is reasonable, but cannot be used to establish the proportions of specific prey species consumed (Herman et al. 2005).

Patterns of persistent organic pollutants (POPs), such as polychlorinated biphenyls (PCBs), dichlor-diphenyl-trichloroethane (DDTs), and polybrominated diphenylethers (PBDEs), have been shown to differentiate cetacean stocks (Muir et al. 1996; Krahn et al. 1999, 2004), presumably due to differences in relative concentrations of POPs in their prey. However, only a few studies have compared patterns or levels of POPs in predators from the Antarctic marine food web to those in similar species from lower latitudes in the Southern and in the Northern Hemispheres. For example, Connell et al. (1999) found that pinnipeds from the Southern Hemisphere had considerably lower POP levels than similar species from the Northern Hemisphere. Additionally, Antarctic minke whales (Aono et al. 1997) and albatrosses (Muir et al. 2002) that feed in Antarctica have been shown to have lower POP concentrations than related species in the North Pacific. Weber and Goerke (1996) reported that POP concentrations (i.e., p,p'-DDE, trans-nonachlor, PCB congeners 138, 153, and 180) in fish from Antarctica were substantially lower than those in fish from the North Sea, but that the concentration of hexachlorobenzene (HCB) was similar in fish from the two areas. In addition, Weber and Goerke (2003) examined how patterns of selected POPs in marine fish differed among species with different feeding habits and how these patterns changed over time. Furthermore, Goerke et al. (2004) found that Weddell seals and southern elephant seals (Mirounga leonina) greatly biomagnified certain POPs relative to Antarctic krill 
(Euphausia superba) and that POP patterns present in the blubber of these pinnipeds also changed with increasing trophic level. Unfortunately, POP levels and patterns cannot be directly and quantitatively compared among killer whales and their likely prey, because individual POPs are biomagnified to a different extent and biomagnification factors appear to be species specific (Fisk et al. 2001, Hoekstra et al. 2003). To date, no biomagnification factors have been reported for killer whales. Thus, until these values are known, only qualitative comparisons are possible.

In the first study of this kind for Antarctic killer whales, chemical tracers (i.e., stable isotopes of carbon and nitrogen, fatty acids, and POPs) were measured in biopsy samples taken from free-ranging Type $\mathrm{C}$ killer whales in the southwestern Ross Sea. To put these results into a more global perspective, they were compared to those from previous studies of killer whales from the ENP and eastern Tropical Pacific Ocean (ETP). In addition, samples from four Antarctic marine fish species were also analyzed for the same chemical tracers and the results were used to infer whether these species were part of the Type $C$ killer whale diet.

\section{METHODS}

\section{Killer Whales Sampled}

Biopsies of Type C killer whales $(n=28)$ were collected from the ice edge in McMurdo Sound, off the west side of Ross Island in the southern Ross Sea, Antarctica, during the austral summer months in two consecutive years, 2005 and 2006 (Table 1). All samples were obtained from live whales using remote biopsy sampling techniques (Hoelzel et al. 1998, Barrett-Lennard 2000, Ylitalo et al. 2001) and biopsy tips of various lengths (typically $3.0-3.5 \mathrm{~cm}$ ). All biopsy samples were stored frozen at $-80^{\circ} \mathrm{C}$ until analyzed. In an attempt to standardize sample size, frozen biopsy samples were subjected to two lateral cuts. First, the epidermis was removed by cutting the sample 1-2 $\mathrm{mm}$ from the inside edge of the epidermis and then a second lateral cut was made $2 \mathrm{~cm}$ from the inside edge of the epidermis (sample length $\sim 1.8 \mathrm{~cm}$ ). The blubber and epidermis biopsy samples from the whales listed in Table 1 were analyzed for fatty acids, POPs, and stable isotopes of carbon and nitrogen. To date, no stranded killer whales have been examined in Antarctica in order to assess the blubber thickness of this population. However, in the ENP, numerous strandings of killer whales have occurred and blubber thicknesses on the upper back behind the dorsal fin was measured to be in the range of $5-8 \mathrm{~cm}$ for a typical adult whale. Because Type $\mathrm{C}$ whales are now known to be a substantially smaller form of killer whale (Pitman et al. 2007), it is unlikely that the blubber thickness of the Antarctic population is comparable to that of killer whales in the ENP. However, a 2-cm biopsy sample is still unlikely to include a substantial quantity of the metabolically active inner-blubber layer.

Blubber samples from Antarctic Type $C$ killer whales of both sexes were analyzed for POPs. However, only the POP results for the adult male killer whales $(n=7)$ were compared to other populations of adult male killer whales. Reproductive females transfer a portion of their contaminant burden to their calves, so POP concentrations in females are generally lower than in males and are dependent on the number of times they have given birth (Ross et al. 2000, Ylitalo et al. 2001, Borga et al. 2004). 
Table 1. Collection date, age class, and location for Antarctic Type $\mathrm{C}$ and eastern Tropical Pacific killer whale biopsy samples analyzed for fatty acids (FA), stable isotopes (SI), and persistent organic pollutants (POPs).

\begin{tabular}{|c|c|c|c|c|c|c|}
\hline Sample & FA & SI & $\mathrm{POPs}^{\mathrm{a}}$ & $\begin{array}{c}\text { Collection } \\
\text { date }\end{array}$ & $\begin{array}{l}\text { Age } \\
\text { class }\end{array}$ & $\begin{array}{c}\text { SWFSC } \\
\text { ID }^{\mathrm{b}}\end{array}$ \\
\hline \multicolumn{7}{|c|}{ Antarctic Type $C^{c}$} \\
\hline \multicolumn{7}{|l|}{ Males } \\
\hline 1 & $\mathrm{x}$ & $\mathrm{x}$ & $\mathrm{x}$ & $1 / 24 / 2005$ & Adult & Z45799 \\
\hline 2 & $\mathrm{x}$ & $\mathrm{x}$ & $\mathrm{x}$ & $1 / 24 / 2005$ & Adult & Z45800 \\
\hline 3 & $\mathrm{x}$ & $\mathrm{x}$ & $\mathrm{x}$ & $1 / 24 / 2005$ & Adult & Z45803 \\
\hline 4 & $\mathrm{x}$ & $\mathrm{x}$ & $\mathrm{x}$ & $1 / 24 / 2005$ & Adult & Z45804 \\
\hline 5 & $\mathrm{x}$ & $\mathrm{x}$ & $\mathrm{x}$ & $1 / 25 / 2005$ & Adult & Z45805 \\
\hline 6 & $\mathrm{x}$ & $\mathrm{x}$ & $\mathrm{x}$ & $1 / 25 / 2005$ & Adult & Z45806 \\
\hline 7 & $\mathrm{x}$ & $\mathrm{x}$ & & $1 / 31 / 2006$ & Subadult & Z53852 \\
\hline 8 & $\mathrm{x}$ & $\mathrm{x}$ & & $1 / 31 / 2006$ & Subadult & Z53854 \\
\hline 9 & $\mathrm{x}$ & $\mathrm{x}$ & & $2 / 1 / 2006$ & Adult & Z53851 \\
\hline 10 & $\mathrm{x}$ & $\mathrm{x}$ & & $2 / 1 / 2006$ & Subadult & Z53859 \\
\hline 11 & $\mathrm{x}$ & $\mathrm{x}$ & $\mathrm{x}$ & $2 / 2 / 2006$ & Adult & Z53857 \\
\hline 12 & $\mathrm{x}$ & $\mathrm{x}$ & & $2 / 2 / 2006$ & Subadult & Z53860 \\
\hline 13 & $\mathrm{x}$ & $\mathrm{x}$ & & $2 / 2 / 2006$ & Subadult & Z53861 \\
\hline \multicolumn{7}{|c|}{ Females } \\
\hline 14 & $\mathrm{x}$ & $\mathrm{x}$ & & $1 / 21 / 2005$ & Adult & Z45808 \\
\hline 15 & $\mathrm{x}$ & $\mathrm{x}$ & & $1 / 21 / 2005$ & Adult & Z45809 \\
\hline 16 & $\mathrm{x}$ & $\mathrm{x}$ & & $1 / 21 / 2005$ & Adult & Z45810 \\
\hline 17 & $\mathrm{x}$ & $\mathrm{x}$ & & $1 / 21 / 2005$ & Adult & Z45811 \\
\hline 18 & $\mathrm{x}$ & $\mathrm{x}$ & & $1 / 21 / 2005$ & Adult & Z45812 \\
\hline 19 & $\mathrm{x}$ & $\mathrm{x}$ & & $1 / 21 / 2005$ & Adult & Z45813 \\
\hline 20 & $\mathrm{x}$ & $\mathrm{x}$ & & $1 / 24 / 2005$ & Adult & Z45801 \\
\hline 21 & $\mathrm{x}$ & $\mathrm{x}$ & & $1 / 24 / 2005$ & Adult & Z45802 \\
\hline 22 & $\mathrm{x}$ & $\mathrm{x}$ & & $1 / 25 / 2005$ & Adult & Z45807 \\
\hline 23 & $\mathrm{x}$ & $\mathrm{x}$ & & $1 / 23 / 2006$ & Unknown & Z53862 \\
\hline 24 & $\mathrm{x}$ & $\mathrm{x}$ & & $1 / 23 / 2006$ & Unknown & Z53863 \\
\hline 25 & $\mathrm{x}$ & $\mathrm{x}$ & & $1 / 23 / 2006$ & Unknown & Z53864 \\
\hline 26 & $\mathrm{x}$ & $\mathrm{x}$ & & $2 / 1 / 2006$ & Unknown & Z53855 \\
\hline 27 & $\mathrm{x}$ & $\mathrm{x}$ & & $2 / 1 / 2006$ & Unknown & Z53856 \\
\hline 28 & $\mathrm{x}$ & $\mathrm{x}$ & & $2 / 1 / 2006$ & Unknown & Z53858 \\
\hline \multicolumn{7}{|c|}{ Eastern Tropical Pacific (used for comparison) ${ }^{c}$} \\
\hline \multicolumn{7}{|l|}{ Males } \\
\hline 1 & & & $\mathrm{x}$ & $9 / 26 / 2003$ & Adult & Z38168 \\
\hline 2 & & & $\mathrm{x}$ & 9/26/2003 & Unknown & Z38170 \\
\hline 3 & & & $\mathrm{x}$ & 9/26/2003 & Unknown & Z38175 \\
\hline
\end{tabular}

${ }^{a}$ Although POP analyses were conducted for all killer whales in this table, only adult males " $x$ " were used for POP concentrations (Table 4) and PCB profiles (Fig. 3). One Adult male (Z53851) was not included in POP analyses due to low percent lipid (<5\%).

${ }^{b}$ Southwest Fisheries Science Center specimen identification number for Antarctic Type C and Eastern Tropical Pacific samples.

'Positions for samples collected: Antarctica, 21 January 2005, (77 $\left.32^{\prime} \mathrm{S}, 165^{\circ} 45^{\prime} \mathrm{E}\right) ; 24$ and 25 January $2005,\left(77^{\circ} 32^{\prime} \mathrm{S}, 165^{\circ} 16^{\prime} \mathrm{E}\right) ; 23$ January $2006,\left(77^{\circ} 33^{\prime} \mathrm{S}, 165^{\circ} 58^{\prime} \mathrm{E}\right) ; 31$ January 2006, $\left(77^{\circ} 33^{\prime} \mathrm{S}, 165^{\circ} 56^{\prime} \mathrm{E}\right) ; 1$ February 2006, ( $\left.77^{\circ} 27^{\prime} \mathrm{S}, 165^{\circ} 36^{\prime} \mathrm{E}\right) ; 2$ February 2006, $\left(77^{\circ} 29^{\prime} \mathrm{S}, 165^{\circ} 57^{\prime} \mathrm{E}\right.$ and $\left.77^{\circ} 27^{\prime} \mathrm{S}\right), 165^{\circ} 45^{\prime} \mathrm{E}$. Eastern Tropical Pacific, 26 September $2003,\left(10^{\circ} 58^{\prime} \mathrm{N}, 88^{\circ} 40^{\prime} \mathrm{W}\right)$. 


\section{Killer Whale Prey Sampled}

Samples of one Antarctic minke whale and four species of marine fish that were potential prey of the Antarctic Type $C$ killer whales were also collected from McMurdo Sound, Ross Sea, Antarctica, and were analyzed for fatty acids, POPs, and stable isotopes. Fish species included: dusky notothen (Trematomus newnesi, $n=2$ adults), bald notothen (Pagothenia borchgrevinki, $n=2$ adults), Antarctic toothfish ( $n=1$ adult), and Antarctic silverfish (Pleuragramma antarcticum, $n=5$ juveniles). Specimens were collected in January 2005, except the silverfish collected in 2000 and the minke whale biopsied in 2006. Unfortunately, tissue samples from other potential prey species (marine fish and mammals) were not available at the time of this study.

\section{Fatty Acid, Stable Isotope, and POP Analyses}

Blubber samples from the killer whales and minke whale were analyzed for fatty acids and POPs and the epidermis was analyzed for stable isotopes. Individual, whole fish were ground to a homogenous mixture and subsamples of the homogenate were analyzed for fatty acids, POPs, and stable isotopes.

Fatty acid concentrations were determined as reported by Krahn et al. (2004) and fatty acid concentration data were expressed as weight percent of total fatty acids. The n-number standard nomenclature system was used for abbreviating the names of these fatty acids, where the number following the " $\mathrm{n}$ " symbol in the abbreviation refers to the carbon position of the first double bond relative to the alkyl end of the molecule. A full list of all 83 fatty acids measured as part of this study, as well as their abbreviations, systematic, and trivial names can be found in Table 1 of Krahn et al. (2004). These 83 fatty acids, listed by n-number nomenclature, are also found in Appendix S1.

Stable isotope analyses were conducted as described previously by Herman et al. (2005). All tissues were lipid extracted prior to stable isotope analysis. Stable isotope values were expressed in $\delta$ notation as parts per mil (\%0) by the following expression:

$$
\delta Z=[(\text { Rsample } / \text { Rstd })-1] \times 1,000
$$

where $Z$ represents ${ }^{15} \mathrm{~N}$ or ${ }^{13} \mathrm{C}$ and Rsample is the ratio ${ }^{15} \mathrm{~N} /{ }^{14} \mathrm{~N}$ or ${ }^{13} \mathrm{C} /{ }^{12} \mathrm{C}$ for the tissue sample. Here, Rstd is the ratio ${ }^{15} \mathrm{~N} /{ }^{14} \mathrm{~N}$ or ${ }^{13} \mathrm{C} /{ }^{12} \mathrm{C}$ of the reference standard. All nitrogen values were referenced to atmospheric nitrogen $\left(\delta^{15} \mathrm{~N}\right.$ for atmospheric $\mathrm{N}_{2}$ is $0 \%$ exactly) and carbon values were referenced to Vienna Pee Dee Belemnite (a.k.a. $\delta^{13}$ C of NBS $19 \equiv 1.95 \%$, Coplen et al. 2006). The daily laboratory standards were calibrated using the following primary standard values: NBS-22 $\left(\delta^{13} \mathrm{C}=\right.$ -30.03), IAEA-CH-6 $\left(\delta^{13} \mathrm{C}=-10.45\right)$, IAEA-N-1 $\left(\delta^{15} \mathrm{~N}=0.43\right)$, and IAEA$\mathrm{N}-2\left(\delta^{15} \mathrm{~N}=20.39\right)$. Maximum standard deviations allowed for replicate analyses for $\delta^{13} \mathrm{C}$ and $\delta^{15} \mathrm{~N}$ in the calibration standards were $\leq \pm 0.3 \%$ and $\leq \pm 0.2 \%$, respectively.

POP concentrations were determined using the procedure of Sloan et al. (2004). A total of 40 PCB congeners, 24 chlorinated pesticides, and 10 PBDE congeners were determined in these samples; see Sloan et al. (2004) for a list of all POP analytes measured. In this article, $\sum \mathrm{PCBs}$ is the sum of all $40 \mathrm{PCB}$ congeners analyzed; $\sum$ DDTs is the sum of $\mathrm{o}, \mathrm{p}^{\prime}, \mathrm{p}^{\prime}-\mathrm{DDD}, \mathrm{p}, \mathrm{p}^{\prime}-\mathrm{DDE}, \mathrm{o}, \mathrm{p}^{\prime}-\mathrm{DDE}, \mathrm{o}, \mathrm{p}^{\prime}-\mathrm{DDT}$, and $\mathrm{p}, \mathrm{p}^{\prime}-\mathrm{DDT}$; $\sum$ chlordanes is the sum of oxychlordane, gamma-chlordane, nonachlor III, alpha-chlordane, trans-nonachlor, and cis-nonachlor; $\sum$ hexachlorocyclohexanes 
( $\sum \mathrm{HCHs}$ ) is the sum of alpha-, beta-, and gamma-HCH isomers; and finally, $\sum$ PBDEs is the sum of congeners $28,47,49,66,85,99,100,153,154,183$. Total lipids, as well as lipid classes, were measured in the samples by a TLC-FID method (Ylitalo et al. 2005).

\section{Statistical Analyses}

Unless indicated otherwise, all multivariate and univariate analyses were conducted on nontransformed data using either JMP Statistical Discovery Software (PC profession edition, version 5.01) or Primer-e (PC edition, version 6.1.6). Differences in absolute POP levels were examined by comparing POP concentrations expressed on a lipid-normalized basis (ng/g total lipid). In addition, individual PCB congener concentration data were expressed as weight percent of all $40 \mathrm{PCBs}$ to normalize the results so that any differences in measured PCB patterns was independent of absolute tissue concentrations. All principal component analyses (PCA) were performed on the correlation matrix computed from these compositional data.

Multidimensional scaling analysis (MDS) of the fatty acid data was performed using the Primer-E statistical software package. Prior to MDS analysis, the fatty acid weight percent composition data were pretreated by: (1) normalizing the weight percent of each individual fatty acid among all samples within the data set, (2) computing an among-sample dissimilarity matrix based on Euclidean distances between the variables, and (3) subjecting the dissimilarity matrix to classical multidimensional scaling analysis. The sample-to-sample proximity values (dissimilarities) resulting from the MDS analysis were then plotted in the form of a two-dimensional perceptual map.

\section{RESULTS}

\section{Stable Isotope Values}

The mean $\delta^{13} \mathrm{C}$ and $\delta^{15} \mathrm{~N}$ values for Type $\mathrm{C}$ killer whales (Table 2) were significantly lower $(P<0.05)$ compared to Northern Hemisphere killer whale groups. Approximate trophic levels were calculated with Equation 4 from Hodum and Hobson (2000) using $\delta^{15} \mathrm{~N}$ values for three different fish-eating killer whale populations and regionally specific zooplankton data from the literature (Schell et al. 1998, Kline 1999, Hodum and Hobson 2000). The results were: Antarctic Type $\mathrm{C}$ killer whales $=$ 5.5; eastern Aleutian Island residents $=5.3$; Gulf of Alaska residents $=5.1$.

Four species of possible Antarctic fish prey had measured $\delta^{13} \mathrm{C}$ values that were similar to each other (Table 3; Fig. 1) and, among all the killer whale groups listed, were most similar to those measured in the Type $C$ killer whale population. The Antarctic silverfish, dusky notothen, and bald notothen also had mean $\delta^{15} \mathrm{~N}$ values that were very similar to each other (Table 3; Fig. 1). These prey were about one trophic level lower than Type $C$ whales, assuming $\delta^{15} \mathrm{~N}$ enrichment values of about +3.3 units per trophic level in this ecosystem (Wada et al. 1987) and $\delta^{13} \mathrm{C}$ enrichment of +1.3 units per trophic level (Hobson et al. 1996, 2002). The $\delta^{15} \mathrm{~N}$ and $\delta^{13} \mathrm{C}$ values for the "Antarctic Type C estimated diet" were calculated by subtracting the $\delta^{15} \mathrm{~N}$ and $\delta^{13} \mathrm{C}$ values trophic enrichment values from those for Type $\mathrm{C}$ whales (Fig. 1). The single Antarctic toothfish had a higher $\delta{ }^{15} \mathrm{~N}$ value than that found for all but one of the Type $\mathrm{C}$ whales (Table 2, 3). 
Table 2. Mean $( \pm 1 \mathrm{SD})$ carbon and nitrogen stable isotope values in epidermis of selected killer whale populations. ${ }^{a}$

\begin{tabular}{|c|c|c|c|c|}
\hline SWFSC ID & Sex & & $\delta^{13} \mathrm{C}$ & $\delta^{15} \mathrm{~N}$ \\
\hline \multicolumn{5}{|c|}{ Antarctic Type $\mathrm{C}$ males ${ }^{\mathrm{b}}$} \\
\hline Z45799 & Adult & & $-23.7 \pm 0.1$ & $13.3 \pm 0.3$ \\
\hline Z45800 & Adult & & $-24.1 \pm 0.1$ & $13.1 \pm 0.2$ \\
\hline Z45803 & Adult & & $-23.6 \pm 0.2$ & $13.4 \pm 0.3$ \\
\hline Z45804 & Adult & & $-23.8 \pm 0.1$ & $14.1 \pm 0.2$ \\
\hline Z45805 & Adult & & $-23.9 \pm 0.1$ & $12.8 \pm 0.2$ \\
\hline Z45806 & Adult & & $-23.5 \pm 0.1$ & $13.7 \pm 0.2$ \\
\hline Z53852 & Subadult & & $-24.1 \pm 0.1$ & $13.2 \pm 0.3$ \\
\hline Z53854 & Subadult & & $-24.1 \pm 0.1$ & $13.4 \pm 0.3$ \\
\hline Z53851 & Adult & & $-23.9 \pm 0.1$ & $13.1 \pm 0.3$ \\
\hline Z53859 & Subadult & & $-24.0 \pm 0.1$ & $12.9 \pm 0.3$ \\
\hline Z53857 & Adult & & $-24.0 \pm 0.1$ & $13.3 \pm 0.3$ \\
\hline Z53860 & Subadult & & $-24.0 \pm 0.1$ & $12.9 \pm 0.3$ \\
\hline Z53861 & Subadult & & $-23.7 \pm 0.1$ & $12.9 \pm 0.3$ \\
\hline \multicolumn{2}{|c|}{ Mean for males $(n=13)$} & & $-23.9 \pm 0.2$ & $13.2 \pm 0.4$ \\
\hline \multicolumn{5}{|c|}{ Antarctic Type C females ${ }^{b}$} \\
\hline Z45808 & Adult & & $-23.8 \pm 0.1$ & $13.5 \pm 0.2$ \\
\hline Z45809 & Adult & & $-23.9 \pm 0.1$ & $13.3 \pm 0.2$ \\
\hline Z45810 & Adult & & $-23.6 \pm 0.2$ & $13.6 \pm 0.2$ \\
\hline Z45811 & Adult & & $-23.7 \pm 0.1$ & $13.7 \pm 0.2$ \\
\hline Z45812 & Adult & & $-24.0 \pm 0.1$ & $12.6 \pm 0.2$ \\
\hline Z45813 & Adult & & $-23.8 \pm 0.1$ & $13.0 \pm 0.2$ \\
\hline Z45801 & Adult & & $-23.8 \pm 0.1$ & $12.9 \pm 0.2$ \\
\hline Z45802 & Adult & & $-23.5 \pm 0.2$ & $13.6 \pm 0.3$ \\
\hline Z45807 & Adult & & $-23.4 \pm 0.1$ & $13.5 \pm 0.2$ \\
\hline Z53862 & Unknown & & $-23.8 \pm 0.1$ & $13.4 \pm 0.3$ \\
\hline Z53863 & Unknown & & $-24.1 \pm 0.1$ & $12.8 \pm 0.3$ \\
\hline Z53864 & Unknown & & $-24.2 \pm 0.1$ & $12.8 \pm 0.3$ \\
\hline Z53855 & Unknown & & $-23.9 \pm 0.1$ & $12.5 \pm 0.3$ \\
\hline Z53856 & Unknown & & $-23.9 \pm 0.1$ & $13.0 \pm 0.3$ \\
\hline Z53858 & Unknown & & $-23.9 \pm 0.1$ & $13.1 \pm 0.3$ \\
\hline \multicolumn{2}{|c|}{ Mean for females $(n=15)$} & \multicolumn{2}{|r|}{$-23.8 \pm 0.2$} & $13.2 \pm 0.4$ \\
\hline \multicolumn{2}{|c|}{ Comparison groups } & Sample size & $\delta^{13} \mathrm{C}$ & $\delta^{15} \mathrm{~N}$ \\
\hline \multicolumn{2}{|c|}{ Alaska residents } & 79 & $-16.7 \pm 1.3$ & $16.4 \pm 1.5$ \\
\hline \multicolumn{2}{|c|}{ Alaska offshores } & 5 & $-16.8 \pm 0.3$ & $17.0 \pm 0.3$ \\
\hline \multicolumn{2}{|c|}{ Alaska transients } & 47 & $-16.3 \pm 0.8$ & $17.7 \pm 1.5$ \\
\hline \multicolumn{2}{|c|}{ West Coast (California) transients } & 10 & $-15.9 \pm 0.6$ & $18.7 \pm 1.2$ \\
\hline
\end{tabular}

${ }^{a}$ Values for Alaska residents, offshores and transients, and West Coast transients are from Herman et al. (2005) and Krahn et al. (2007).

${ }^{\mathrm{b}}$ Both carbon and nitrogen values were statistically significantly different $(P<0.05)$ from those of the other killer whale populations. 
Table 3. Mean ( $\pm 1 \mathrm{SD})$ stable isotope values measured in possible Antarctic prey species, as well as literature values for additional potential prey species.

\begin{tabular}{|c|c|c|c|}
\hline Animal ID (n) & Tissue & $\delta^{13} \mathrm{C}$ & $\delta^{15} \mathrm{~N}$ \\
\hline \multicolumn{4}{|l|}{ Antarctic fish (measured values) } \\
\hline Dusky notothen ( $n=2 ;$ small adults) & Whole & $-25.2,-24.7$ & $10.4,11.4$ \\
\hline Bald notothen ( $n=2$; small adults) & Whole & $-26.0,-24.3$ & $10.1,11.2$ \\
\hline Antarctic silverfish ( $n=5$; juveniles) & Whole & $-24.3 \pm 0.3$ & $10.3 \pm 0.4$ \\
\hline Antarctic toothfish $(n=1 ;$ adult $)$ & Muscle & -26.3 & 14.0 \\
\hline Antarctic minke whale $(n=1)$ & Skin & -24.3 & 7.6 \\
\hline \multicolumn{4}{|l|}{ Antarctic prey (literature values) } \\
\hline $\begin{array}{l}\text { Antarctic silverfish (Pleuragramma } \\
\quad \text { antarcticum; } n=13 \text {; adults) }^{\mathrm{a}}\end{array}$ & Whole & $-23.9 \pm 0.7$ & $10.7 \pm 1.2$ \\
\hline $\begin{array}{l}\text { Deepwater notothen (Trematomus } \\
\quad \text { loennbergii; } n=2)^{\mathrm{b}}\end{array}$ & Muscle & $-26.8,-24.5$ & $10.3,13.4$ \\
\hline $\begin{array}{l}\text { Weddell seals (Leptonychotes weddellii; } \\
\quad n=12)^{\mathrm{b}}\end{array}$ & Plasma & $-25.5 \pm 0.1$ & $13.1 \pm 0.2$ \\
\hline Eelpout (Rhigophilia dearborni; $n=1)^{\mathrm{b}}$ & Muscle & -23.6 & 13.2 \\
\hline Emerald rockcod $(T \text {. bernaccbii; } n=\text { ? })^{\mathrm{c}}$ & $?$ & -23.4 & 10.4 \\
\hline $\begin{array}{l}\text { Adélie penguin (Pygoscelis adeliae; } \\
\quad \text { Prydz Bay; } n=8)^{\mathrm{d}}\end{array}$ & Muscle & $-23.4 \pm 0.1$ & $9.3 \pm 0.2$ \\
\hline Icefish (Chionodraco hamatus; $n=8)^{\mathrm{d}}$ & ? & $-22.5 \pm 0.3$ & $12.6 \pm 0.3$ \\
\hline $\begin{array}{l}\text { Crabeater seal (Lobodon carcinophagus; } \\
\quad n=30 \text {; adult) }\end{array}$ & Serum & $-26.5 \pm 1.0$ & $8.4 \pm 0.6$ \\
\hline Ross seal $(\text { Ommotophoca rossii; } n=21)^{\mathrm{e}}$ & Serum & $-24.3 \pm 0.4$ & $10.6 \pm 0.6$ \\
\hline $\begin{array}{l}\text { Leopard seal (Hydrurga leptonyx; } n= \\
2)^{\mathrm{e}}\end{array}$ & Serum & $-24.8 \pm 0.3$ & $12.3 \pm 0.5$ \\
\hline $\begin{array}{l}\text { Antarctic krill (Euphausia superba; } n= \\
\quad 12 ; \text { adults })^{\mathrm{f}}\end{array}$ & Muscle & $-29.8 \pm 0.6$ & $3.6 \pm 0.2$ \\
\hline $\begin{array}{l}\text { Adélie penguin }(\text { Pygoscelis adeliae; } \\
\quad \text { Palmer Station; } n=6)^{\mathrm{f}}\end{array}$ & Muscle & $-23.7 \pm 0.3$ & $12.5 \pm 1.6$ \\
\hline
\end{tabular}

${ }^{\mathrm{a}}$ Hodum and Hobson (2000), ${ }^{\mathrm{b}}$ Burns et al. (1998), ${ }^{\mathrm{c}}$ Wada et al. (1987), ${ }^{\mathrm{d}}$ Hall-Aspland et al. (2005), ${ }^{\mathrm{e} Z}$ Zhao et al. (2004), ${ }^{\mathrm{f}}$ Dunton (2001), ${ }^{\mathrm{g}}$ Cherel and Hobson (2007).

\section{Fatty Acid Compositions and Profiles}

Among the 83 individual fatty acids measured in the blubber of the Antarctic killer whales, only 55 were routinely present at weight percent values above the method quantitation limits (ca., $0.01 \%$; see Appendix S1). Consequently, in this study, a fatty acid profile is defined as the multidimensional vector comprising the fatty acid weight percent values for each of these 55 fatty acids and includes both exogenous (dietary) and endogenous (nondietary) fatty acids. Mean summed weight percent values are also reported in Appendix S1 for several classes of fatty acids measured in individual Antarctic Type $C$ killer whales and their potential prey.

Similarities in the fatty acid profiles among Antarctic Type $\mathrm{C}$ and three other killer whale populations (offshore, Alaska resident, and Alaska transient; Herman et al. 2005, Krahn et al. 2007) were evaluated by subjecting these compositional data to a multidimensional scaling analysis and depicting the similarities among the groups as a two-dimensional perceptual map (Fig. 2). 


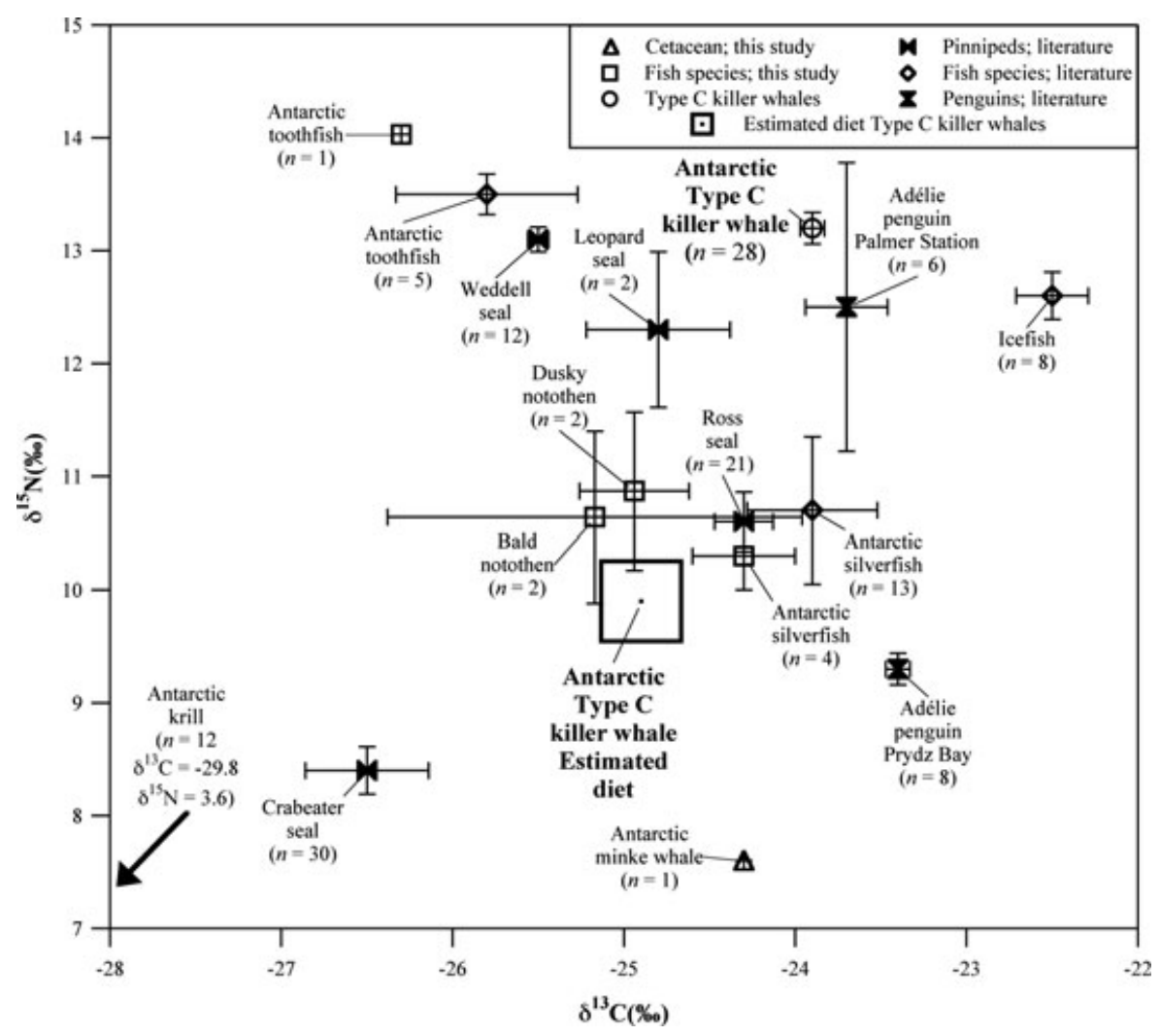

Figure 1. Nitrogen and carbon stable isotope values for Type $\mathrm{C}$ killer whales and potential Antarctic prey species (mean $\pm 95 \%$ confidence intervals). See Table 1 for references for those carbon and nitrogen stable isotope values obtained from the literature.

\section{POP Concentrations and Patterns}

Mean concentrations in all groups of POPs (Table 4, Appendix S2) were significantly higher $(P<0.05)$ in adult male Type $C$ killer whales than in Type $C$ females. Because POP concentrations in killer whales generally increase with age in males (Ross et al. 2000), their concentrations are often highly variable. POP concentrations (ng/g lipid) in adult male Type $\mathrm{C}$ killer whales were also compared to those in adult males for other groups of killer whales - offshores, Alaska residents, and Alaska transients, West Coast (California) transients and ETP whales (Table 4). Type $\mathrm{C}$ whales had the lowest mean concentrations for all groups of POPs, except for HCB. For example, the mean $\sum$ PCB and $\sum$ DDT concentrations in adult male Type $C$ whales, relative to those from the other five killer whale groups (Table 4), ranged from $0.23 \%$ to $12 \%$ and from $0.12 \%$ to $20 \%$, respectively. Conversely, mean HCB concentrations measured in Type $\mathrm{C}$ whales were comparable to those in ENP residents and offshores. The Antarctic fish generally had very low concentrations of POPs (Table 4, Appendix S2), with the exception that one of the two bald notothen samples had a relatively high $\sum$ PCBs level, although the other contaminant classes measured in 


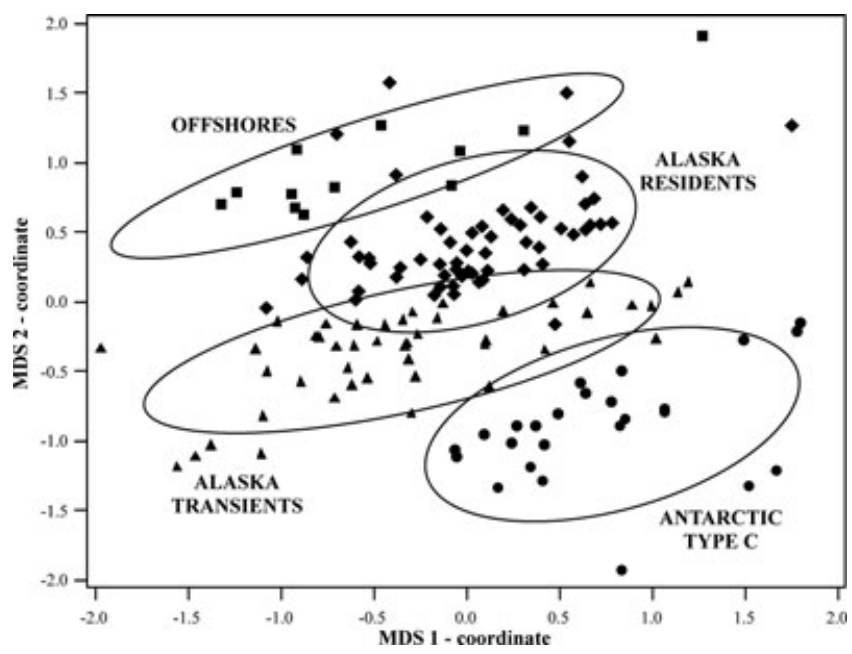

Figure 2. Two-dimensional perceptual map obtained by multidimensional scaling analysis of the fatty acid profiles of Antarctic Type $\mathrm{C}$ and Alaskan resident, offshore, and transient killer whales. Each point in this plot represents the fatty acid profile of an individual whale where the Euclidean distance between any two points is proportional to the intersample difference between their normalized fatty acid profiles. The fatty acid profiles include both exogenous (dietary) and endogenous (nondietary) fatty acids for the 55 fatty acids present above method quantitation limits. Fatty acid data for the Alaska killer whale populations were obtained from Herman et al. (2005) and Krahn et al. (2007).

this single fish sample were quite low. In addition, the Antarctic toothfish had higher concentrations of $\sum$ DDTs, $\sum$ chlordanes, and HCB than were found for the other Antarctic fish. Concentrations of POPs were much lower in the single minke whale than those found for the Type $C$ whales and approximately the same magnitude as those found for the Antarctic toothfish (Table 4).

PCB weight percent composition data, i.e., the PCB congener profiles, for Type $\mathrm{C}$ killer whales were compared to the other populations (adult males only) using a principal component analysis. A two-dimensional PCA plot was created to assess the extent to which these contaminant patterns differ among these spatially and ecologically distinct groups (Fig. 3). In this plot, the first and second principal components (PC1 and PC2) accounted for 54\% and $20 \%$ of the total variance, respectively. The relative orientations of the eigenvector projections corresponding to the $12 \mathrm{PCB}$ congeners responsible for the observed separations among individuals and among groups are also depicted (Fig. 3). The PCB profiles of Antarctic Type C killer whales were highly dissimilar to those of the other four killer whale populations, largely because the former had a high relative abundance of higher chlorinated PCB congeners in their blubber tissues, particularly congeners PCB 149 and PCB 170.

\section{DisCUSSION}

Antarctic Type $\mathrm{C}$ killer whales were shown to have fatty acid, stable isotope, and POP profiles that were very different from those of the ENP and ETP killer whale populations. Although Type $\mathrm{C}$ whales have only been observed to feed on 


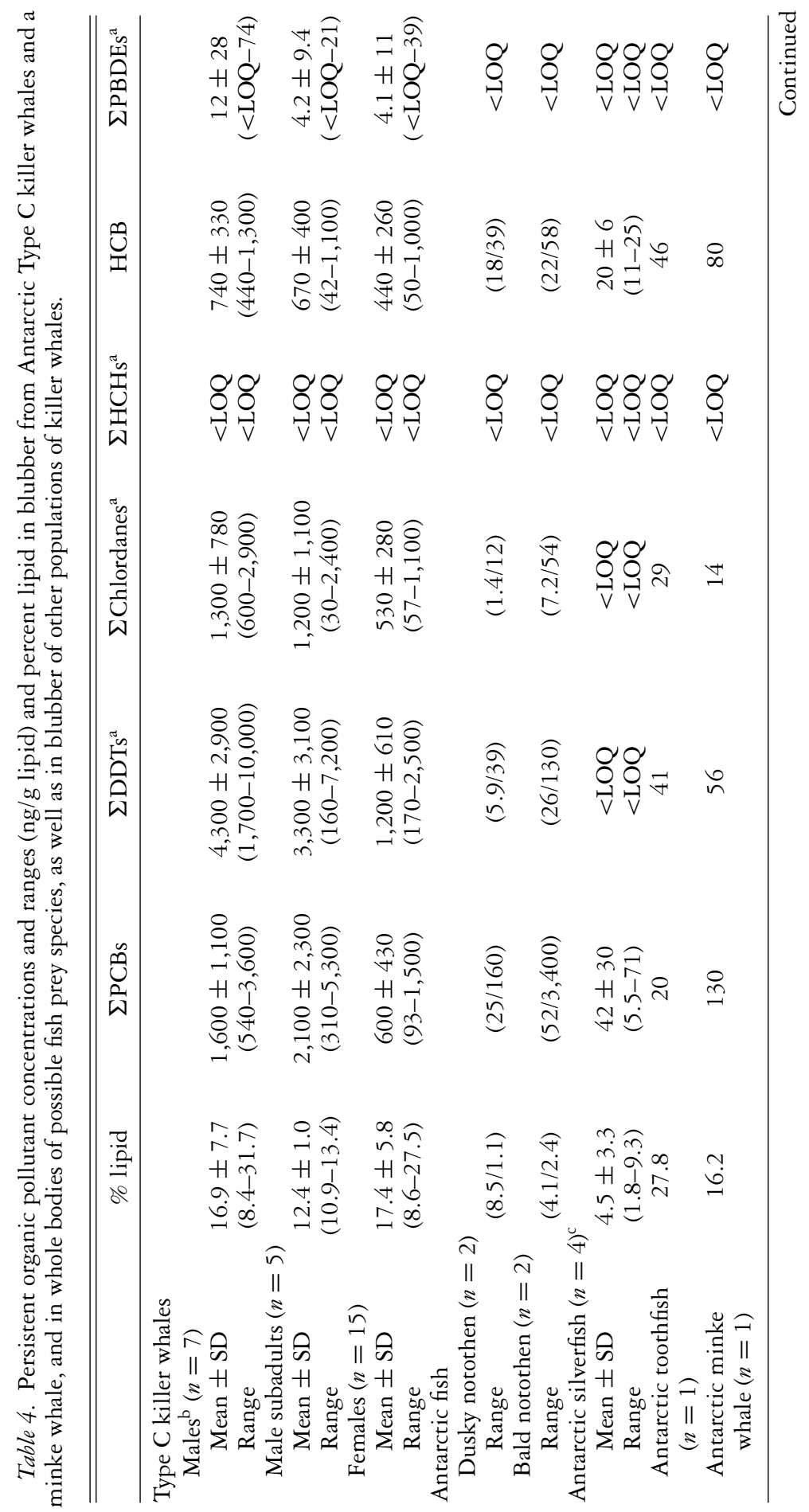




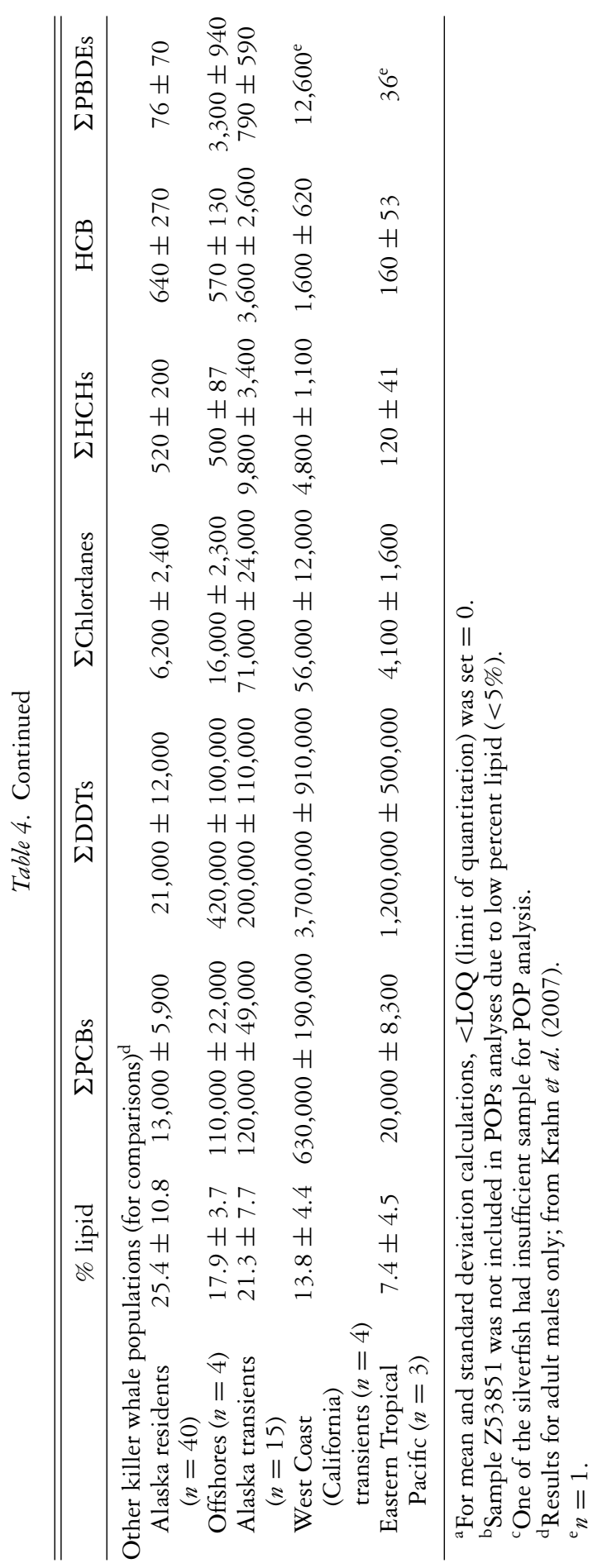




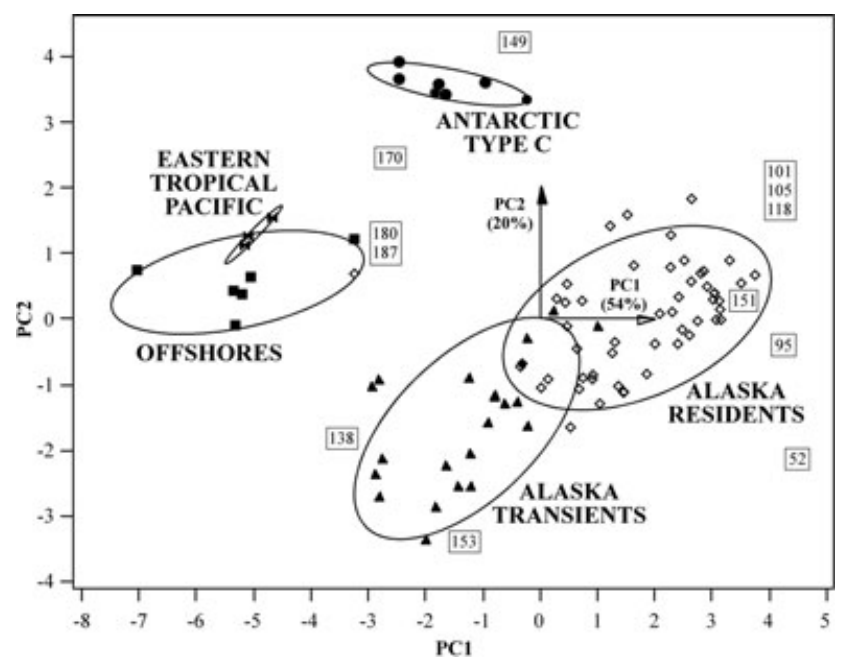

Figure 3. Principal component (PC) analysis depicting the differences in the PCB profiles of adult male killer whales from the Antarctic, eastern North Pacific, and eastern Tropical Pacific zones. The relative orientations of the eigenvectors corresponding to the 12 specific PCB congeners responsible for the observed separation among the regional killer whale groups and ecotypes are also shown. PCB data for the Alaska killer whale populations were obtained from Herman et al. (2005) and Krahn et al. (2007).

marine fish, chemical tracer results from this study suggested that other prey groups (e.g., lower trophic-level marine mammal, penguin, or cephalopod species) could be important constituents of their overall diet. Ostensibly, the significantly lower values for nitrogen stable isotopes would seem to indicate that Type $C$ whales feed at a trophic level that is lower than those of the fish-eating killer whale populations studied in the other regions (Herman et al. 2005, Krahn et al. 2007). However, when the approximate trophic levels for the presumed fish-eating Type $\mathrm{C}$ whales were calculated using established correction factors (Schell et al. 1998, Kline 1999, Hodum and Hobson 2000), Type C and ENP resident killer whales occupied approximately the same trophic level (5.5 and 5.3, respectively). Thus, the lower-than-expected carbon and nitrogen stable isotope values observed in the Antarctic Type $\mathrm{C}$ killer whales (Table 2, Fig. 1) were likely the result of the much reduced $\delta^{13} \mathrm{C}$ and $\delta^{15} \mathrm{~N}$ values that exist at the base of the food chain in the coastal Antarctic ecosystem (Goericke and Fry 1994, Cabana and Rasmussen 1996). With respect to Antarctic $\delta^{13} \mathrm{C}$ values in particular, the low values can be partly explained by the decrease in ${ }^{13} \mathrm{C}$ enrichment that generally occurs with decreasing water temperatures (Sackett et al. 1965).

The stable isotope values offer some insight into the possible prey species of Type $\mathrm{C}$ killer whales. The $\delta^{15} \mathrm{~N}$ values in the single adult Antarctic toothfish collected for this study $\left(\delta^{15} \mathrm{~N}=14.0, n=1\right)$, as well as in toothfish reported by Burns et al. (1998) $\left(\delta^{15} \mathrm{~N}=13.5 \pm 0.2, n=5\right)$ were very similar to those for Type $\mathrm{C}$ killer whales. Thus, the two species appear to feed at nearly the same trophic level, decreasing the likelihood that adult toothfish are a major diet component of Type $\mathrm{C}$ whales. This apparent exclusion of Antarctic toothfish as a primary prey species was rather unexpected because, even though there have been very few observations 
of feeding to date, toothfish have been the only prey observed (Pitman and Ensor 2003, Ainley et al. 2006). On the other hand, stable isotope analyses indicated that three other common Antarctic nototheniids (Antarctic silverfish, dusky notothen, and bald notothen) had carbon and nitrogen isotope values that were about one trophic level lower than values measured in Type $C$ whales. Therefore, those species (individually or in combination) may be major components in the diet of Type $\mathrm{C}$ whales, in particular, the silverfish that represent more than $90 \%$ of the abundance and biomass of the midwater fish fauna in the waters of the Ross Sea (DeWitt 1970, La Mesa et al. 2004). Silverfish and the two notothens are all small species (maximum length $28 \mathrm{~cm}$ ) that killer whales would probably swallow whole underwater, whereas the toothfish are large enough (up to at least $175 \mathrm{~cm}$ and $100 \mathrm{~kg}$; Collins 2006) that large individuals are likely to be brought to the surface to be eaten or shared (Ford and Ellis 2006). Thus, when interpreting Type $C$ prey preferences, the very visible consumption of toothfish might account for the seeming contradiction between the field observations and stable isotope results.

Predation on pinnipeds, other cetaceans, or penguins — or a mixed diet including both fish and nonfish species - could also be consistent with these stable isotope data. Unfortunately, tissue samples from other potential prey species were not available for this study. A very recent study (Lauriano et al. 2007) conducted in the eastern Ross Sea of Antarctica reported observations of killer whale feeding behavior they interpreted as being consistent with predation on high biomass, schooling fish (e.g., notothenoids). Thus, although the prey species analyzed for this study are by no means inclusive of all the potential prey of Type $C$ killer whales, they represent many of the species currently believed to be likely prey of these whales.

The fatty acid profiles of Type $C$ killer whales as a group were substantially different from those of Alaska killer whales (Fig. 2). Although some overlap was evident among individuals from each of the four populations, previous studies (Herman et al. 2005, Krahn et al. 2007) have demonstrated that a simple linear combination of five specific individual fatty acids was sufficient to unambiguously classify (separate) each of the three Alaska killer whale ecotypes from one another using discriminant function analysis. Somewhat surprisingly, the profiles indicated that Type $\mathrm{C}$ killer whales were marginally more similar to the mammal-eating transients than they were to the fish-eating populations in Alaska. These results could indicate that the Antarctic Type $\mathrm{C}$ killer whales supplement a fish diet with marine mammal prey. Alternatively, the observation may result from (1) highly dissimilar fatty acid compositions in the fish species that inhabit these two largely dissimilar ecosystems; or (2) differential stratification of individual fatty acids within the blubber column owing to factors such as highly dissimilar oceanographic conditions (e.g., temperature, salinity). Interestingly, Type $C$ whales have not been observed preying on other marine mammals and penguins (Pitman and Ensor 2003, Ballard and Ainley 2005), even when these species occur in close proximity (RLP, personal observation). Thus, additional samples of other potential prey species (including nonfish prey) must be analyzed and fatty acid stratification in the blubber of Type $C$ killer whales must be fully characterized to enable the fatty acid profiles to be more informatively compared.

With the exception of the highly volatile pesticide HCB, mean lipid-normalized POP concentrations in adult male Antarctic Type C killer whales (Table 4) were much lower than those reported for the fish-eating Alaska resident or offshore killer whales (Herman et al. 2005, Krahn et al. 2007). These results were not surprising considering the isolation of Antarctica and its small human population (ranges from about 1,000 people in the austral winter to a high of 4,000 in the austral summer). 
Presumably, a majority of these pollutants have been transported to the region via the atmosphere or oceanic currents (Wania and Mackay 1996). Although it is not currently known if Type $\mathrm{C}$ whales are resident in Antarctica or whether they migrate to lower latitudes during the winter (Pitman and Ensor 2003), migration could increase their exposure to pollutants. Regardless, Type $\mathrm{C}$ killer whales have the lowest levels of POPs (except HCB) of any killer whale population studied to date. In contrast, when POP concentrations in adult male Type $C$ killer whales were compared to those of male Antarctic minke whales sampled in western Antarctica (1992/1993, $n=20$; Aono et al. 1997) and to the single Antarctic minke whale biopsied in 2006 (Table 4), $\sum$ PCBs, $\sum$ DDTs, $\sum$ chlordanes, and HCB were found to be several times higher in the killer whales. Most of the differences in concentrations in the two species were likely due to the low levels of contaminants in krill that dominate the minke whale diet compared to higher levels of contaminants in fish or other higher trophic level species that comprise the Type $\mathrm{C}$ diet. Although modest increases in pollution levels were documented in both western and eastern Antarctica between the mid-1980s and early 1990s (Aono et al. 1997, Goerke et al. 2004), the minke whale blubber collected in 2006 (Table 4) had POP concentrations similar to or lower than those in minke whales sampled in the early 1990s. Thus, temporal trends alone are not likely to account for the large magnitude differences ( $\sim 5-90$-fold) observed in POP concentrations between killer and minke whales.

PCB patterns in the blubber of the Antarctic Type $C$ killer whales were also very different from those of the other killer whale populations (Fig. 3), primarily due to a high relative abundance of higher chlorinated congeners (particularly PCB 149 and PCB 170) in Type $C$ whales. Because point sources of pollution in Antarctica are relatively rare, the PCBs acquired by the biota from the region are generally the lower molecular weight congeners that can be transported via the atmosphere or ocean (Wania and Mackay 1996). However, certain areas in McMurdo Sound have been documented to contain high, but patchy concentrations of the anthropogenically introduced Aroclor 1260 (one of several technical mixtures of PCBs) that contains the higher chlorinated congeners (Risebrough et al. 1990, Geochemical and Environmental Research Group 2003). This may explain why blubber of the adult male Type $C$ killer whales contained high molecular weight PCB congeners characteristic of Aroclor 1260, as well as smaller proportions of the lower molecular weight congeners typical of atmospheric transport.

In summary, chemical tracer results were consistent with a diet of fish for Antarctic Type C killer whales in the southwestern Ross Sea, although these whales may supplement their diet with other species (e.g., cetaceans, pinnipeds, penguins, or cephalopods). A mixed diet of fish and other marine species cannot not be ruled out until data from a sufficient number of representative samples of these prey species have been investigated. Furthermore, Type $C$ whales had the lowest concentrations of POPs (except HCBs) yet recorded for any killer whale population, presumably due to their isolation in Antarctic waters. Additional studies that compare chemical tracers in all three killer whale ecotypes in Antarctica will be important in specifying the role of these large and abundant predators in the Antarctic marine food web.

\section{ACKNOWLEDGMENTS}

We greatly appreciate the technical assistance of D. W. Brown, G. M. Ylitalo, C. A. Sloan, R. H. Boyer, D. Boyd, K. Tilbury, G. Yanagida, and J. L. Bolton in sample and data 
analysis. N. Black of the Monterey Bay Whale Watch generously provided samples of the West Coast/California killer whales. We would also like to thank the laboratory staff of the SWFSC Population Identity Program, especially, K. Coultrup, N. M. Hedrick, A. R. Lang, and K. M. Robertson for generating a portion of the genetic data used in this manuscript. P. Cziko and A. DeVries generously provided Antarctic fish samples for analysis. Field work for RLP at McMurdo was supported by grants from National Science Foundation (OPP-0338428) and the U.S. Marine Mammal Commission. Finally, we are grateful for the funding support of T. K. Rowles from the Marine Mammal Health and Stranding Response Program of NOAA Fisheries. Killer whale biopsy samples were collected under MMPA permit 774-1714-00 and Antarctic Conservation Area permit ACA 2004-009M\#2; analyses were conducted under MMPA permit 932-1489-07.

\section{Literature Cited}

Ainley, D. G., G. Ballard and K. M. Dugger. 2006. Competition among penguins and cetaceans reveals trophic cascades in the western Ross Sea. Antarctica Ecology 87:20802093.

Aono, S., S. Tanabe, Y. Fujise, H. Kato and R. Tatsukawa. 1997. Persistent organochlorines in minke whale (Balaenoptera acutorostrata) and their prey species from the Antarctic and the North Pacific. Environmental Pollution 98:81-89.

Baird, R. W., P. A. Abrams AND L. M. Dill. 1992. Possible indirect interactions between transient and resident killer whales: Implications for the evolution of foraging specializations in the genus Orcinus. Oecologia (Berlin) 89:125-132.

Ballard, G., AND D. G. Ainley. 2005. Killer whale harassment of Adélie Penguins at Ross Island. Antarctic Science 17:385-386.

Barrett-Lennard, L. G. 2000. Population structure and mating patterns of killer whales as revealed by DNA analysis. Ph.D. thesis, University of British Columbia, Vancouver, BC. 108 pp.

Barrett-Lennard, L. G., J. K. B. Ford and K. A. Heise. 1996. The mixed blessing of echolocation: Differences in sonar use by fish-eating and mammal-eating killer whales. Animal Behaviour 51:553-565.

Berzin, A. A., And V. L. Vladimirov. 1983. A new species of killer whale (Cetacea, Delphinidae) from the Antarctic waters. Zoologichesky Zhurnal 62:287-295. (In Russian).

BIGG, M. A. 1982. An assessment of killer whale (Orcinus orca) stocks off Vancouver Island, British Columbia. Report of the International Whaling Commission 32:655-666.

Borga, K., A. T. Fisk, P. F. Hoekstra and D. C. G. Muir. 2004. Biological and chemical factors of importance in the bioaccumulation and trophic transfer of persistent organochlorine contaminants in arctic marine food webs. Environmental Toxicology and Chemistry 23:2367-2385.

Burns, J. M., S. J. Trumble, M. A. Castellini and J. W. Testa. 1998. The diet of Weddell seals in McMurdo Sound, Antarctica as determined from scat collections and stable isotope analysis. Polar Biology 19:272-282.

Cabana, G., AND J. B. Rasmussen. 1996. Comparison of aquatic food chains using nitrogen isotopes. Proceedings of the National Academy of Sciences of the United States of America 93:10844-10847.

Cherel, Y., AND K. A. Hobson. 2007. Geographical variation in carbon stable isotope signatures of marine predators: A tool to investigate their foraging areas in the Southern Ocean. Marine Ecology-Progress Series 329:281-287.

Coluins, M. 2006. Toothfish. Pages 1002-1004 in B. Riffenburgh, ed. Encyclopedia of the Antarctic. Routledge, New York, NY.

Connell, D. W., G. J. Miller, M. R. Mortimer, G. R. Shaw and S. M. Anderson. 1999. Persistent lipophilic contaminants and other chemical residues in the Southern Hemisphere. Critical Reviews in Environmental Science and Technology 29:47-82. 
Coplen, T. B., W. A. Brand, M. Gehre, M. Gröning, H. A. J. Meijer, B. Toman and R. M. Verkouteren. 2006. New guidelines for d13C measurements. Analytical Chemistry 78:2439-2441.

Dahl, T. M., L. C., K. M. Kovacs, S. Falk-Peterson, J. Sargent, I. Gjertz and G. B. GULLIKSEN. 2000. Fatty acid composition of the blubber in white whales (Delphinapterus leucas). Polar Biology 23:401-409.

DeNiRo, M. J., AND S. EPSTEIN. 1978. Influence of diet on the distribution of carbon isotopes in animals. Geochim Cosmochim Acta 42:495-506.

DeNiro, M. J., AND S. Epstein. 1981. Influence of diet on the distribution of nitrogen isotopes in animals. Geochim Cosmochim Acta 45:341-351.

DeWitt, H. H. 1970. The character of the midwater fish fauna of the Ross Sea, Antarctica. Pages 305-314 in M. W. Holdgate, ed. Antarctic Ecology. Academic Press, London, UK.

Dunton, K. H. 2001. $\delta^{15} \mathrm{~N}$ and $\delta^{13} \mathrm{C}$ measurements of Antarctic Peninsula fauna: Trophic relationships and assimilation of benthic seaweeds. American Zoologist 41:99112.

Fisk, A. T., K. A. Hobson And R. J. Norstrom. 2001. Influence of chemical and biological factors on trophic transfer of persistent organic pollutants in the Northwater Polynya marine food web. Environmental Science \& Technology 35:732-738.

FORD, J. K. B., AND G. M. ElLIs. 2006. Selective foraging by fish-eating killer whales Orcinus orca in British Columbia. Marine Ecology Progress Series 316:185-199.

Ford, J. K. B., G. M. Ellis, L. G. Barrett-Lennard, A. B. Morton, R. S. Palm and K. C. BALCOMB. 1998. Dietary specialization in two sympatric populations of killer whales (Orcinus orca) in coastal British Columbia and adjacent waters. Canadian Journal of Zoology 76:1456-1471.

Ford, J. K. B., G. M. Ellis AND K. C. BALCOMB. 2000. Killer whales: The natural history and genealogy of Orcinus orca in British Columbia and Washington State. 2nd edition. UBC Press, Vancouver, BC, Canada.

ForNeY, K. A., AND P. R. WADE. 2006. Worldwide distribution and abundance of killer whales. Pages 145-162 in J. A. Estes, D. P. Demaster, D. F. Doak, T. M. Williams and R. L. Brownell Jr., eds. Whales, whaling, and ocean ecosystems. University of California Press, Berkeley, CA.

Fox-Dobbs, K., J. K. Bump, R. O. Peterson, D. L. Fox And P. L. Koch. 2007. Carnivorespecific stable isotope variables and variation in the foraging ecology of modern and ancient wolf populations: Case studies from Isle Royale, Minnesota, and La Brea. Canadian Journal of Zoology 85:458-471.

Geochemical And Environmental Research Group. 2003. Spatial and temporal scales of human disturbance: McMurdo Station, Antarctica. Texas A\&M University and University of Texas, Austin, College Station and Austin, TX.

GILL, P. C., AND D. Thiele. 1997. A winter sighting of killer whales (Orcinus orca) in Antarctic sea ice. Polar Biology 17:401-404.

Goericke, R., AND B. FrY. 1994. Variation of marine plankton $\delta^{13} \mathrm{C}$ with latitude, temperature, and dissolved $\mathrm{CO}_{2}$ in the world ocean. Global Biogeochemical Cycles 8: $85-90$.

Goerke, H., K. Weber, H. Bornemann, S. Ramdohr and J. Plotz. 2004. Increasing levels and biomagnification of persistent organic pollutants (POPs) in Antarctic biota. Marine Pollution Bulletin 48:295-302.

Hall-Aspland, S. A., T. L. Rogers and R. B. Canfield. 2005. Stable carbon and nitrogen isotope analysis reveals seasonal variation in the diet of leopard seals. Marine Ecology Progress Series 305:249-259.

Herman, D. P., D. G. Burrows, P. R. Wade, J. W. Durban, R. G. Leduc, C. O. Matkin and M. M. KRAHN. 2005. Feeding ecology of eastern North Pacific killer whales from fatty acid, stable isotope, and organochlorine analyses of blubber biopsies. Marine Ecology Progress Series 302:275-291. 
Hobson, K. A., AND H. E. Welch. 1992. Determination of trophic relationships within a high Arctic marine food web using $\delta^{13} \mathrm{C}$ and $\delta^{15} \mathrm{~N}$ analysis. Marine Ecology Progress Series 84:9-18.

Hobson, K. A., D. M. Schell, D. Renouf And E. Noseworthy. 1996. Stable carbon and nitrogen isotopic fractionation between diet and tissues of captive seals: Implications for dietary reconstructions involving marine mammals. Canadian Journal of Fisheries and Aquatic Sciences 53:528-533.

Hobson, K. A., A. Fisk, N. Karnovsky, M. Holst, J.-M. Gagnon and M. Fortier. 2002. A stable isotope $\left(\delta^{13} \mathrm{C}, \delta^{15} \mathrm{~N}\right)$ model for the North Water food web: Implications for evaluating trophodynamics and the flow of energy and contaminants. Deep Sea Research Part II 49:5131-5150.

Hodum, P. J., AND K. A. Hobson. 2000. Trophic relationships among Antarctic fulmarine petrels: Insights into dietary overlap and chick provisioning strategies inferred from stable-isotope $\left(\delta^{15} \mathrm{~N}\right.$ and $\left.\delta^{13} \mathrm{C}\right)$ analyses. Marine Ecology Progress Series 198:273-281.

Hoekstra, P. F., T. M. O’Hara, A. T. Fisk, K. Borga, K. R. Solomon and D. C. G. MUIR. 2003. Trophic transfer of persistent orgranochlorine contaminants (OCs) within an Arctic marine food web from the southern Beaufort-Chukchi Seas. Environmental Pollution 124:509-522.

Hoelzel, A. R., M. Dahlheim and S. J. Stern. 1998. Low genetic variation among killer whales (Orcinus orca) in the eastern north Pacific and genetic differentiation between foraging specialists. Journal of Heredity 89:121-128.

Hooker, S. K., S. J. Iverson, P. Ostrom And S. C. Smith. 2001. Diet of northern bottlenose whales inferred from fatty-acid and stable-isotope analyses of biopsy samples. Canadian Journal of Zoology 79:1442-1454.

Iverson, S. J., C. Field, W. D. BOWEn AND W. Blanchard. 2004. Quantitative fatty acid signature analysis: A new method of estimating predator diets. Ecological Monographs 74:211-235.

Jehl, J. R., JR., W. E. Evans, F. T. Awbrey and W. S. Drieschmann. 1980. Distribution and geographic variation in the killer whale (Orcinus orca) populations of the Antarctic and adjacent waters. Antarctic Journal of the United States 15:161-163.

Jones, I. M. 2006. A northeast Pacific offshore killer whale (Orcinus orca) feeding on a Pacific halibut (Hippoglossus stenolepis). Marine Mammal Science 22:198-200.

KELLY, J. F. 2000. Stable isotopes of carbon and nitrogen in the study of avian and mammalian trophic ecology. Canadian Journal of Zoology 78:1-27.

KLINE, T. C., JR. 1999. Temporal and spatial variability of $13 \mathrm{C} / 12 \mathrm{C}$ and $15 \mathrm{~N} / 14 \mathrm{~N}$ in pelagic biota of Prince William Sound. Canadian Journal of Fisheries and Aquatic Sciences 56:94-117.

KoOpman, H. N., S. J. Iverson AND D. E. GASKIN. 1996. Stratification and age-related differences in blubber fatty acids of the male harbour porpoise (Phocoena phocoena). Journal of Comparative Physiology. Part B 165:628-639.

Krahn, M. M., D. G. Burrows, J. E. Stein, P. R. Becker, M. M. Schantz, D. C. Muir and T. M. O'HarA. 1999. White whales (Delphinapterus leucas) from three Alaskan stocks: Concentrations and patterns of persistent organochlorine contaminants in blubber. Journal of Cetacean Research and Management 1:239-249.

Krahn, M. M., D. P. Herman, G. M. Ylitalo, C. A. Sloan, D. G. Burrows, R. C. Hobbs, B. A. Mahoney, G. K. Yanagida, J. Calambokidis and S. E. Moore. 2004. Stratification of lipids, fatty acids and organochlorine contaminants in blubber of white whales and killer whales. Journal of Cetacean Research and Management 6:175-189.

Krahn, M. M., D. P. Herman, C. O. Matkin, J. W. Durban, L. Barrett-Lennard, D. G. Burrows, M. E. Dahlheim, N. Black, R. G. Leduc and P. R. Wade. 2007. Use of chemical tracers in assessing the diet and foraging regions of eastern North Pacific killer whales. Marine Environmental Research 63:91-114.

La Mesa, M., J. T. EAstman And M. VACCHI. 2004. The role of notothenioid fish in the food web of the Ross Sea shelf waters: A review. Polar Biology 27:321-338. 
Lauriano, G., C. M. Fortuna And M. Vacchi. 2007. Observation of killer whale (Orcinus orca) possibly eating penguins in Terra Nova Bay, Antarctica. Antarctic Science 19:9596.

Mikhalev, Y. A., M. V. Ivashin, V. P. Savusin and F. E. Zelanaya. 1981. The distribution and biology of killer whales in the Southern Hemisphere. Report of the International Whaling Commission 31:551-566.

Muir, D. C. G., C. A. Ford, B. Rosenberg, R. J. Norstrom, M. Simon and P. Beland. 1996. Persistent organochlorines in beluga whales (Delphinapterus leucas) from the St. Lawrence River Estuary-I. Concentrations and patterns of specific PCBs, chlorinated pesticides and polychlorinated dibenzo-p-dioxins and dibenzofurans. Environmental Pollution 93:219-234.

Muir, D. C. G., P. D. Jones, H. Karlsson, K. Koczansky, G. A. Stern, K. Kannan, J. P. Ludwig, H. Reid, C. J. R. Robertson and J. P. Giesy. 2002. Toxaphene and other persistent organochlorine pesticides in three species of albatrosses from the North and South Pacific Ocean. Environmental Toxicology and Chemistry 21:413423.

Olsen, E., AND O. Grahl-Nielsen. 2003. Blubber fatty acids of minke whales: Stratification, population identification and relation to diet. Marine Biology 142:13-24.

Pitman, R. L., And P. Ensor. 2003. Three forms of killer whales (Orcinus orca) in Antarctic waters. Journal of Cetacean Research and Management 5:131-139.

Pitman, R. L., W. L. Perryman, D. Leroi AND E. Eilers. 2007. A dwarf form of killer whale in Antarctica. Journal of Mammalogy 88:43-48.

Risebrough, R. W., B. W. Delappe and C. Younghans-Haug. 1990. PCB and PCT contamination in Winter Quarters Bay, Antarctica. Marine Pollution Bulletin 21:523529.

Ross, P. S., G. M. Ellis, M. G. Ikonomou, L. G. Barrett-lennard and R. F. Addison. 2000. High PCB concentrations in free-ranging Pacific killer whales, Orcinus orca: Effects of age, sex and dietary preference. Marine Pollution Bulletin 40:504-515.

Sackett, W. M., W. R. Eckelmann, M. L. Bender and A. W. H. Be. 1965. Temperature dependence of carbon isotope composition in marine plankton and sediments. Science 148:235-237.

Schell, D. M., B. A. Barnett And K. A. VinetTe. 1998. Carbon and nitrogen isotope ratios in zooplankton of the Bering, Chukchi and Beaufort seas. Marine Ecology Progress Series 162:11-23.

Sloan, C. A., D. W. Brown, R. W. Pearce, R. H. Boyer, J. L. Bolton, D. G. Burrows, D. P. Herman AND M. M. KRaHn. 2004. Northwest Fisheries Science Center procedures for extraction, cleanup and gas chromatography/mass spectrometry analysis of sediments and tissues for organic contaminants. NOAA Tech Memo NMFS/NWFSC-59, U. S. Department of Commerce, Seattle, WA.

Thomas, J. A., S. Leatherwood, W. E. Evans, J. R. Jehl and F. T. Awbrey. 1981. Ross sea killer whale distribution, behavior, color pattern and vocalizations. Antarctic Journal of the United States 1981 Review16:157-158.

Tieszen, L. L., T. W. Boutton, K. G. Tesdahl and N. A. Slade. 1983. Fractionation and turnover of stable carbon isotopes in animal tissues: Implications for $\delta^{13} \mathrm{C}$ analysis of diet. Oecologia (Berlin) 57:32-37.

Tollit, D. J., M. Steward, P. M. Thompson, G. J. Pierce, M. B. Santos and S. Hughes. 1997. Species and size differences in the digestion of otoliths and beaks: Implications for estimates of pinniped diet composition. Canadian Journal of Fisheries and Aquatic Sciences 54:105-119.

Visser, I. N. 1999. Antarctic orca in New Zealand waters? New Zealand Journal of Marine and Freshwater Research 33:515-520.

Wada, E., M. Terazaki, Y. Kabaya and T. Nemoto. 1987. N-15 and C-13 abundances in the Antarctic Ocean with emphasis on the biogeochemical structure of the food web. Deep Sea Research Part A Oceanographic Research Papers 34:829-841. 
Walton, M. J., R. J. Henderson And P. P. Pomeroy. 2000. Use of blubber fatty acid profiles to distinguish dietary differences between grey seals Halichoerus grypus from two UK breeding colonies. Marine Ecology Progress Series 193:201-208.

WANIA, F., AND D. MACKAY. 1996. Tracking the distribution of persistent organic pollutants. Environmental Science \& Technology 30:A390-A396.

Weber, K., AND H. Goerke. 1996. Organochlorine compounds in fish off the Antarctic Peninsula. Chemosphere 33:377-392.

Weber, K., AND H. Goerke. 2003. Persistent organic pollutants (POPs) in Antarctic fish: Levels, patterns, changes. Chemosphere 53:667-678.

Ylitalo, G. M., C. O. Matkin, J. Buzitis, M. M. Krahn, L. L. Jones, T. Rowles and J. E. STEIN. 2001. Influence of life-history parameters on organochlorine concentrations in free-ranging killer whales (Orcinus orca) from Prince William Sound, AK. Science of the Total Environment 281:183-203.

Ylitalo, G. M., G. K. Yanagida, L. Hufnagle, Jr. and M. M. Krahn. 2005. Determination of lipid classes and lipid content in tissues of aquatic organisms using a thin layer chromatography/flame ionization detection (TLC/FID) microlipid method. Pages 449464 in G. K. Ostrander, ed. Techniques in aquatic toxicology. CRC Press, Boca Raton, FL.

Yonezaki, S., M. KiYota, N. Baba, T. Koido and A. Takemura. 2003. Size distribution of the hard remains of prey in the digestive tract of northern fur seal (Callorbinus ursinus) and related biases in diet estimation by scat analysis. Mammal Study 28:97-102.

Zhao, L. Y., M. A. Castellini, T. L. Mau and S. J. Trumble. 2004. Trophic interactions of Antarctic seals as determined by stable isotope signatures. Polar Biology 27:368-373.

Received: 12 February 2007 Accepted: 26 February 2008

\section{SUPPLEMENTARY MATERIAL}

The following supplementary material is available for this article online: Appendix S1. Fatty acid compositions ${ }^{\mathrm{a}, \mathrm{b}}$ (weight percent) of individual Antarctic Type C killer whales and selected Antarctic putative prey analyzed as part of this study.

Appendix S2. Persistent organic pollutant (POP) concentrations ${ }^{\mathrm{a}, \mathrm{b}}$ for Antarctic Type C killer whale biopsy and possible prey samples. 